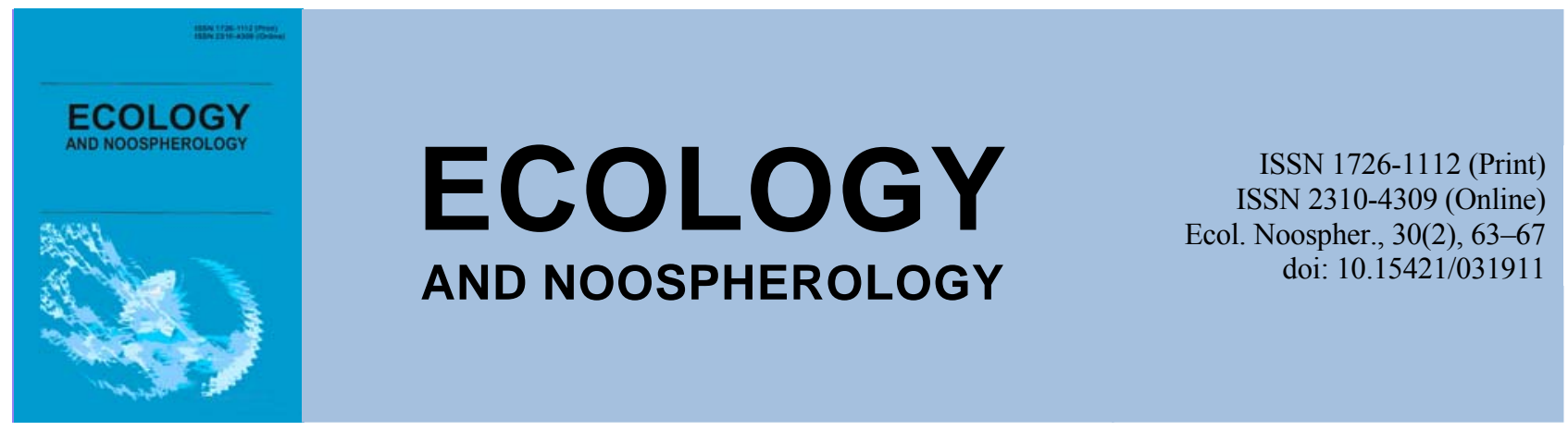

\title{
Wastewater bioremediation with using of phototrophic non-sulfur bacteria Rhodopseudomonas yavorovii IMV B-7620
}

\author{
O. V. Tarabas*, S. O. Hnatush*, O. M. Moroz*, M. M. Kovalchuk** \\ *Ivan Franko National University of Lviv, Lviv, Ukraine \\ **LLC «Girhimprom Institute» of the Academy of Mining Sciences of Ukraine, Lviv, Ukraine
}

Article info

Received 03.04.2019

Received in revised form 14.04.2019

Accepted 24.04.2019

Ivan Franko National University of Lviv, Hrushevskyi Str., 4,

Lviv, 79005, Ukraine.

Tel.: +38-067-291-08-68

E-mail: otarabas@gmail.com

LLC «Girhimprom Institute» of the Academy of Mining Sciences of Ukraine, Striyska Str., 98, Lviv, 79030, Ukraine.
Tarabas, O. V., Hnatush, S. O., Moroz, O. M., Kovalchuk, M. M. (2019). Wastewater bioremediation with using of phototrophic non-sulfur bacteria Rhodopseudomonas yavorovii IMV B-7620. Ecology and Noospherology, 30(2), 63-67. doi:10.15421/031911

Phototrophic purple non-sulfur bacteria (PNSB) mineralize organic waste. In media with different organic substances they are metabolized from simple aliphatic organic acids to complex polysaccharides. These bacteria can produce $\mathrm{H}_{2}$, indole-3-acetic acid and 5-aminolevulinic acid. PNSB purify waters from hydrogen sulfide and, as components of ecosystem trophic chains, participate in process of sulfur cycle. The ability of these bacteria to denitrification is of particular interest to specialists because nitrates concentrations in industrial effluents are often much higher than the maximum permissible concentrations. The use of industrial, agricultural and household wastes to produce PNSB biomass is economically profitable. Therefore, the aim of our work was to investigate the influence of wastewater of the yeast plant and the water of the settler № 3 filtrate of the Lviv Solid Household Waste Landfill (LSHWL) on the biomass accumulation by PNSB Rhodopseudomonas yavorovii IMV B-7620 and the changes in the composition of these waters in the process of cultivation of the investigated bacteria. Bacteria were grown for 21 days anaerobically at an illumination intensity of 200 lux in $500 \mathrm{ml}$ flasks at $+29 \ldots+30^{\circ} \mathrm{C}$. The wastewater of the yeast plant and the water of the settler № 3 filtrate of the LSHWL were used as the cultivation media. Water was diluted at $10 ; 30 ; 50 ; 100$ times. In water, diluted at 10 times, the $\mathrm{pH}$, total ferrum content, $\mathrm{Ca}^{2+}, \mathrm{Mg}^{2+}, \mathrm{Cl}^{-}, \mathrm{NO}_{3}^{-}, \mathrm{NO}_{2}^{-}, \mathrm{SO}_{4}{ }^{2-}, \mathrm{HS}^{-}$and chemical oxygen demand (COD) were determined. The biomass of bacteria was measured turbidimetrically at $\lambda=660 \mathrm{~nm}$. The concentration of $\mathrm{HS}^{-}$was determined spectrophotometrically $(\lambda=665 \mathrm{~nm})$ by the formation of methylene blue. The content of sulfate ions was determined turbidimetrically $(\lambda=520 \mathrm{~nm})$ after their precipitation with barium chloride. The concentrations of $\mathrm{Ca}^{2+}$ and $\mathrm{Mg}^{2+}$ were determined titrometrically by reaction with trilon $\mathrm{B} ; \mathrm{Na}^{+}$and $\mathrm{K}^{+}$were analyzed by flame emission spectrometry method $\left(\lambda_{\mathrm{K}}=768 \mathrm{~nm}, \lambda_{\mathrm{Na}}=589 \mathrm{~nm}\right)$. The $\mathrm{pH}$ of the water was measured potentiometrically. The concentration of $\mathrm{Cl}^{-}$was determined titrometrically by reaction with $\mathrm{AgNO}_{3}$. The concentration of nitrite ions was determined spectrophotometrically by the method of sulfanilic acid diazotization by nitrite ions and the interaction of the formed salt with $n$-(naphthyl)ethylenediamine dihydrochloride $(\lambda=540 \mathrm{~nm}, l=10 \mathrm{~mm})$. The concentration of nitrate ions was determined spectrophotometrically by the diazotization method. Zinc powder was used as the reducing agent. COD was measured with using of $\mathrm{KMnO}_{4}$. It is characterised the patterns of biomass accumulation by $R$. yavorovii IMV B7620 bacteria in the wastewater of the yeast plant and the water of the settler № 3 filtrate of the LSHWL, diluted at 10-100 times. The optimal dilution (at 10 times) of water for bacteria cultivation was selected. Bacteria $R$. yavorovii IMV B-7620 accumulate biomass of $2.2 \mathrm{~g} / 1$ during growth in a yeast plant wastewater that is twice as large as the biomass, accumulated by bacteria in the diluted water of the settler № 3 filtrate. The organic compounds oxidation efficiency of the yeast plant wastewater and of the settler № 3 filtrate of LSHWL, determined by chemical oxygen demand, was 42.3 and $65.6 \%$, respectively, on the 21 st day of cultivation. The established possibility of the influence of $R$. yavorovii IMV B-7620 on the decreasing of the content of total $\mathrm{Fe}, \mathrm{Ca}^{2+}, \mathrm{Mg}^{2+}, \mathrm{NO}_{3}^{-}$, $\mathrm{NO}_{2}^{-}, \mathrm{SO}_{4}{ }^{2-}, \mathrm{Cl}^{-}, \mathrm{HS}^{-}$in wastewater has complemented and broadened the understanding of the role of purple non-sulfur bacteria in ecosystems, which can significantly influence on the biogeochemical cycles of these compounds in nature. The results obtained may form the basis for the development of effective biotechnologies for wastewater treatment from hydrogen sulfide, chlorine, ferrum, nitrogen, sulfur compounds with the participation of these microorganisms. 


\title{
Біоремедіація стічних вод за використання фототрофних несіркових бактерій Rhodopseudomonas yavorovii IMB B-7620
}

\author{
О. В. Тарабас*, С. О. Гнатуш*, О. М. Мороз*, М. М. Ковальчук** \\ *Львівський національний університет імені Івана Франка, Львів, Украӥна \\ **ТзОВ «Інститут Гірхімпром» Академії гірничих наук України, Львів, Украӥна
}

Охарактеризовано закономірності нагромадження біомаси бактеріями Rhodopseudomonas yavorovii IMB B-7620 у стічній воді дріжджового заводу та воді фільтрату відстійника № 3 Львівського полігону твердих побутових відходів (ЛПТПВ) за розведення в 10; 30; 50; 100 разів. Підібрано оптимальне розведення води для культивування бактерій. Бактерії $R$. yavorovii IMB B-7620 нагромаджують біомасу 2,2 г/л під час росту у стічній воді дріжджового заводу, яка у 2 рази перевищує біомасу, нагромаджену бактеріями у розведеній воді фільтрату відстійника № 3 ЛПТПВ. Ефективність окиснення органічних сполук стічної води дріжджового заводу та води фільтрату відстійника № 3 ЛПТПВ, визначена за хімічним споживанням кисню, становила 42,3 та 65,6 \% відповідно на 21-шу добу культивування. Встановлена можливість впливу бактерій $R$. yavorovii IMB B-7620 на зменшення вмісту загального $\mathrm{Fe}, \mathrm{Ca}^{2+}, \mathrm{Mg}^{2+}, \mathrm{NO}_{3}^{-}, \mathrm{NO}_{2}^{-}, \mathrm{SO}_{4}^{2-}, \mathrm{Cl}^{-}, \mathrm{HS}^{-}$у стічних водах доповнює та розширює розуміння ролі пурпурових несіркових бактерій в екосистемах, які можуть суттєво впливати на біогеохімічні цикли цих сполук у природі. Отримані результати можуть стати основою для розробки ефективних біотехнологій очищення стічних вод від сірководню, хлору, сполук феруму, нітрогену, сульфуру за участю цих мікроорганізмів.

\section{Ключові слова: біоремедіація стічних вод; фототрофні несіркові бактерії; Rhodopseudomonas}

\section{Вступ}

Технології біоремедіації довкілля грунтуються на використанні природних або генетично сконструйованих мікроорганізмів для відновлення забруднених субстратів i захисту навколишнього середовища. Обробка та утилізація відходів є дуже важливими процесами для зменшення забруднення навколишнього середовища. Значні зусилля вчених були і є спрямовані на дослідження біодеградації органічних забруднювачів (Gibbon and Saylor, 1992; Rhykerd et al., 1999; Merugu et al., 2017). Очищення стічних вод є можливим за участю фототрофних бактерій (Weaver, 1975; Vasavi та ін., 2008). Види пурпурових несіркових бактерій (ПНСБ), що належать до родів Rhodopseudomonas, Rhodospirillum, мінералізують органічні відходи (Thomas et al., 1992; Merugu et al., 2017). ПНСБ були використані для очищення багатьох видів відходів, таких як збагачені латексом стічні води (Choorit et al., 2002), стічні води з акваріумів (Nakadomi et al., 1999) i сільськогосподарські відходи (Hiraishi et al., 1989).

ПНСБ 3 відносно високими темпами росту метаболізують у середовищах 3 різними органічними речовинами: від простих аліфатичних органічних кислот до складних полісахаридів. Тому використання цих мікроорганізмів в очищенні стічних вод вважають ефективним (Sasikala et al., 1993). Крім використання різних органічних сполук вони можуть продукувати $\mathrm{H}_{2}$, індол-3-оцтову кислоту та 5-амінолевулінову кислоту (Rajani et al., 2016). ПНСБ очищують водойми від сірководню i, будучи компонентами трофічних ланцюгів екосистем, беруть участь у процесах колообігу сульфуру (Tarabas et al., 2018).

Використання промислових, сільськогосподарських та комунальних відходів для отримання біомаси ПНСБ є економічно вигідним (Oswald et al., 1975; Mircha et al., 1995). Здатність аноксигенних фототрофних бактерій до денітрифікації та деамоніфікації спричиняє особливий інтерес у фахівців, оскільки в промислових стоках концентрація аміаку та нітратів часто набагато вища гранично допустимих концентрацій (ГДК), що і стає причиною проблем, оскільки такі стічні води скидають у річки та озера (Nagadomi et al., 2000).

Тому метою нашої роботи було дослідження впливу стічної води дріжджового заводу та води фільтрату відстійника № 3 Львівського полігону твердих побутових відходів на нагромадження біомаси ПНСБ $R$. yavorovii IMB В-7620 та зміни складу цих вод у процесі культивування досліджених бактерій.

\section{Матеріали та методи досліджень}

Культуру пурпурових несіркових бактерій $R$. yavorovii IMB В-7620 виділили співробітники кафедри мікробіології ЛНУ імені Івана Франка 3 води озера Яворівське (Львівська область, Україна) (Tarabas et al., 2017a). Бактерії вирощували анаеробно за інтенсивності освітлення 200 лк у колбах об'ємом 500 мл за температури $+29 \ldots+30{ }^{\circ} \mathrm{C}$. Мікроорганізми культивували впродовж 21 доби. Як середовище культивування використовували воду фільтрату відстійника № 3 Львівського полігону твердих побутових відходів та стічну воду дріжджового заводу. Воду розводили в $10,30,50$ та 100 разів.

У воді, розведеній у 10 разів, визначали $\mathrm{pH}$, вміст загального феруму, $\mathrm{Ca}^{2+}, \mathrm{Mg}^{2+}, \mathrm{Cl}^{-}, \mathrm{NO}_{3}^{-}, \mathrm{NO}_{2}^{-}, \mathrm{SO}_{4}^{2-}, \mathrm{HS}^{-}$та хімічне споживання кисню (ХСК). Ці показники були визначені до і під час культивування $R$. yavorovii IMB B-7620.

Біомасу бактерій вимірювали турбідиметрично за використання фотоелектроколориметра КФК-3 ( $\lambda=660$ нм). Концентрацію $\mathrm{HS}^{-}$визначали спектрофотометрично ( $\lambda=665$ нм) за утворенням метиленової сині за використання $n$ амінодиметиланілін дигідрохлориду (Sugiyama, 2002). Вміст сульфат-йонів визначали турбідиметрично $(\lambda=520$ нм) після їх осадження хлоридом барію. Для стабілізації суспензії використовували гліцерин (Gudz et al., 2014; Lur'e, 1984). Концентрації $\mathrm{Ca}^{2+}$ та $\mathrm{Mg}^{2+}$ визначали титрометрично за реакцією 3 трилоном Б; $\mathrm{Na}^{+}$та $\mathrm{K}^{+}$ аналізували за методом полум'яно-емісійної спектрометрії $\left(\lambda_{\mathrm{K}}=768 \mathrm{Hм}, \lambda_{\mathrm{Na}}=589 \mathrm{нм}\right) . \mathrm{pH}$ води вимірювали потенціометрично (pH-метр $150 \mathrm{M}$ ). Концентрацію $\mathrm{Cl}^{-}$визначали титрометрично за реакцією $3 \mathrm{AgNO}_{3}$ (Gudz et al., 2014; Lur'e, 1984). Концентрацію нітрит-іонів визначали методом діазотування сульфанілової кислоти нітрит-іоном і взаємодії утвореної солі 3 -нафтилетилендіаміндигідрохлоридом спектрофотометрично ( $\lambda=540 \mathrm{Hм}, l=10 \mathrm{мm}$ ) (Granger et al., 1996). Концентрацію нітрат-іонів визначали методом діазотування, спектрофотометрично за мутністю розчину $(\lambda=540$ нм, $l=10$ мм). Як відновник використовували цинковий порошок (Granger et al., 1996). Хімічне споживання кисню вимірювали за використання $\mathrm{KMnO}_{4}$ (Fomin, 2008).

Отримані результати опрацьовували статистично 3 використанням програми Microsoft Excel 2017. Досліди повторювали тричі $з$ двома паралельними постановками для кожного варіанта експериментальних та контрольних умов. Для оцінки достовірності різниці між статистичними характеристиками двох альтернативних сукупностей даних 
обраховували коефіцієнт Стьюдента t. Достовірною вважалася різниця при рівні значимості $\mathrm{p} \leq 0,05$ (Lakyn, 1990).

\section{Результати та їх обговорення}

Стічні води дріжджового заводу (табл. 1) та фільтрату відстійника № 3 Львівського полігону твердих побутових відходів (ЛПТПВ) (табл. 2) характеризуються значним вмістом загального феруму, $\mathrm{Ca}^{2+}, \mathrm{Mg}^{2+}, \mathrm{Cl}^{-}, \mathrm{NO}_{3}^{-}, \mathrm{NO}_{2}^{-}$, $\mathrm{SO}_{4}{ }^{2-}, \mathrm{HS}^{-}$, що в десятки, а то й у тисячі разів перевищують ГДК. Це $\epsilon$ однією $з$ причин, чому саме пурпурові несіркові бактерії $R$. yavorovii IMB В-7620 не росли на цій воді без розведення.

Для дослідження нагромадження біомаси $R$. yavorovii IMB В-7620 забруднену воду дріжджового заводу розводили у $10,30,50,100$ разів. Найбільшу біомасу бактерії нагромаджували під час росту у стічній воді, яку розвели в 10 разів. До чотирнадцятої доби культивування біомаса бактерій становила 2,2 г/л та в подальшому залишалася незмінною. Збільшення розведення стічної води до 30, 50 та 100 разів призводило до зниження нагромадження біомаси бактеріями $R$. yavorovii IMB B7620 на 30,$5 ; 29,6 ; 69,1$ \% відповідно на 21-шу добу культивування (рис. 1).

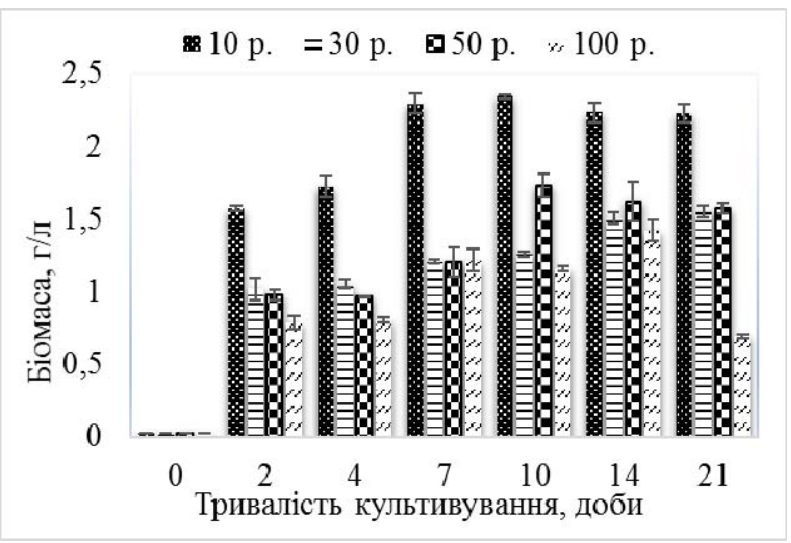

Рис. 1. Нагромадження біомаси бактеріями R. yavorovii IMB В-7620 під час росту у стічній воді дріжджового заводу
На 14-ту добу культивування бактерій у воді фільтрату відстійника № 3 ЛПТПВ, розведеній у 10 разів, біомаса $R$. yavorovii Үа-2016 була 1,1 г/л, що на 26, 4 \% більше, ніж біомаса бактерій, культивованих у цій воді, яку розвели в 30 разів (рис. 2). Збільшення розведення води до 50 та 100 разів спричиняло зниження нагромадження біомаси досліджуваними мікроорганізмами.

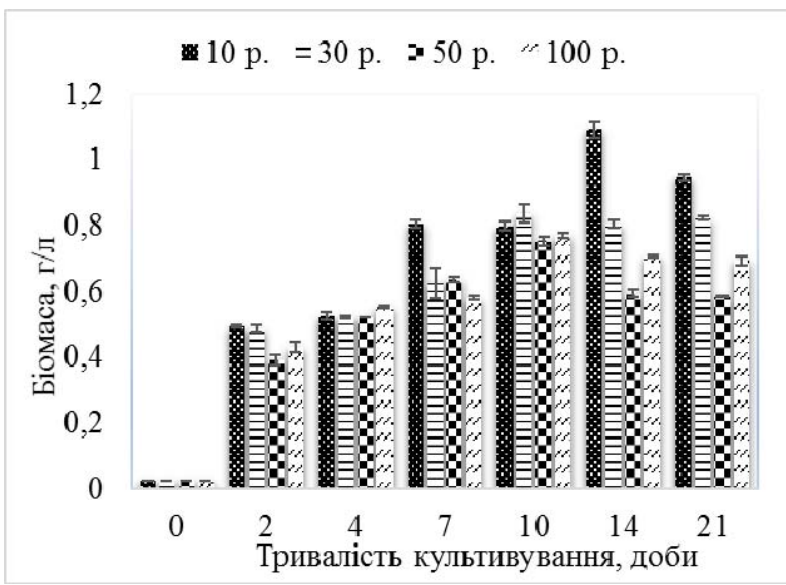

Рис. 2. Нагромадження біомаси бактеріями $R$. yavorovii IMB B-7620 за росту у воді фільтрату відстійника № 3 Львівського полігону твердих побутових відходів

Отже, бактерії $R$. yavorovii IMB B-7620 найкраще ростуть у досліджених стічних водах, розведених у 10 разів.

Значення $\mathrm{pH}$ води залежить від багатьох факторів, насамперед від умісту в ній органічних речовин (Zerkalov, 2007). Для більшості мешканців водних екосистем оптимальне значення $\mathrm{pH}$ не повинне значно відхилятися від нейтрального. Розведена стічна вода дріжджового заводу (контроль) мала $\mathrm{pH} 7,0 \pm 0,1$, що $€$ в межах норми (табл. 1). На

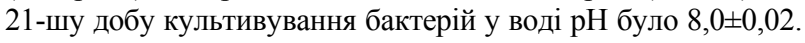
Культивування бактерій у цій воді призводило до зменшення вмісту $\mathrm{Ca}^{2+}$ та $\mathrm{Mg}^{2+}$ упродовж 21 доби (табл. 1). $\mathrm{Mg}^{2+} \quad$ R. yavorovii IMB В-7620 використовували більш інтенсивно, можливо, через те, що магній входить до складу пігментів фототрофних бактерій (Gudz et al., 2011).

Таблиця 1

Вплив культивування $R$. yavorovii IMB В-7620 на хімічний склад стічної води дріжджового заводу

\begin{tabular}{|c|c|c|c|c|c|}
\hline \multirow{4}{*}{ Показник } & \multicolumn{5}{|c|}{ Концентрація, мг/л } \\
\hline & \multirow{3}{*}{ ГДК** } & \multirow{3}{*}{ Контроль } & \multicolumn{3}{|c|}{ Контроль + R. yavorovii IMB В-7620 } \\
\hline & & & \multicolumn{3}{|c|}{ Доба культивування } \\
\hline & & & 7 & 14 & 21 \\
\hline $\mathrm{pH}$ & $6,5-9,0$ & $7,00 \pm 0,10$ & $7,30 \pm 0,01$ & $7,70 \pm 0,01$ & $8,00 \pm 0,02$ \\
\hline Fe загальний & 0,5 & $67,0 \pm 0,05^{*}$ & $52,0 \pm 0,01 *$ & $37,20 \pm 0,02 *$ & $14,20 \pm 0,04^{*}$ \\
\hline $\mathrm{Ca}^{2+}$ & 46,0 & $6012,0 \pm 0,04^{*}$ & $5980,0 \pm 0,01 *$ & $5210,40 \pm 0,06^{*}$ & $5020,80 \pm 0,03 *$ \\
\hline $\mathrm{Mg}^{2+}$ & 50,0 & $7291,20 \pm 0,04 *$ & $4131,70 \pm 0,05^{*}$ & $1944,30 \pm 0,04 *$ & $243,0 \pm 0,02 *$ \\
\hline $\mathrm{NO}_{3}^{-}$ & 12,5 & $2711,30 \pm 0,04 *$ & $1484,60 \pm 0,05^{*}$ & $1345,20 \pm 0,03 *$ & $1282,50 \pm 0,04^{*}$ \\
\hline $\mathrm{NO}_{2}^{-}$ & 1,5 & $2011,60 \pm 0,05^{*}$ & $1101,50 \pm 0,01 *$ & $998,10 \pm 0,02 *$ & $951,50 \pm 0,02 *$ \\
\hline $\mathrm{SO}_{4}{ }^{2-}$ & 500,0 & $3334,20 \pm 0,02 *$ & $1927,90 \pm 0,04 *$ & $1570,40 \pm 0,03 *$ & $1100,10 \pm 0,03 *$ \\
\hline $\mathrm{Cl}^{-}$ & 300,0 & $10344,80 \pm 0,01^{*}$ & $8620,70 \pm 0,03 *$ & $6896,50 \pm 0,04 *$ & $6200,0 \pm 0,04 *$ \\
\hline $\mathrm{HS}^{-}$ & 1,0 & $21473,30 \pm 0,02 *$ & $12266,30 \pm 0,02 *$ & $2851,90 \pm 0,05^{*}$ & $1138,80 \pm 0,03 *$ \\
\hline XCK & 500,0 & $5200,0 \pm 0,03 *$ & $4000,0 \pm 0,02 *$ & $3800,0 \pm 0,01^{*}$ & $3000,0 \pm 0,01 *$ \\
\hline
\end{tabular}

Примітки: * $\mathrm{p} \leq 0,05$; контроль - розведена в 10 разів вода; ** https://omr.gov.ua/ua/projects/3776.

Різні сполуки нітрогену можуть трансформуватися 3 однієї форми в іншу головно у процесі життєдіяльності живих організмів. Високий уміст нітрогену призводить до евтрофікації водних екосистем. Під час культивування бактерій $R$. yavorovii IMB B-7620 у стічній воді дріжджового заводу вміст нітрит- та нітрат-йонів знижувався на 52,7 і 52,7 \% відповідно на 21-шу добу. Спостерігали також зниження вмісту сульфат-йонів на $67,0 \%$. Крім того, на 21-шу добу культивування бактерій $R$. yavorovii IMB B-7620 вміст $\mathrm{Cl}^{-}$зменшився на 40,1 \% (табл. 1). 
R. yavorovii IMB В-7620 використовують гідросульфідйони як донори електронів аноксигенного фотосинтезу (Tarabas et al., 2017b). Концентрація гідросульфід-йонів знизилась на $94,7 \%$ за росту досліджуваних мікроорганізмів у стічній воді дріжджового заводу (табл. 1).

Органічне забруднення води є особливо небезпечним. Органічні речовини, які осідають на дно, вбивають донні мікроорганізми, які беруть участь у процесі самоочищення. У подальшому відбувається загибель фітопланктону та зоопланктону, виділяються шкідливі сполуки, у т.ч. сірководень, які отруюють все живе (Zapolskij and Saljuk, 2008; Togachynska et al., 2014).

Різке зростання ХСК води свідчить про ії забруднення і вимагає застосування відповідних заходів для очищення (Zerkalov, 2007; Togachynska et al., 2014). За значеннями XСК розведеної води перед та після культивування $R$. yavorovii IMB В-7620 визначено, що ефективність окиснення органічних сполук у ній становила $42,3 \%$ на 21-шу добу.

Під час культивування $R$. yavorovii IMB В-7620 у воді фільтрату відстійника № 3 ЛПТПВ, розведеній у 10 разів, біомаса бактерій становила 1,1 г/л на 21-шу добу культивування (рис. 2). Показник $\mathrm{pH}$ змінювався від

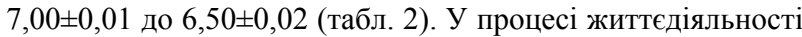
мікроорганізмів відбувалося зниження вмісту загального $\mathrm{Fe}, \mathrm{Ca}^{2+}, \mathrm{Mg}^{2+}, \mathrm{NO}_{3}^{-}, \mathrm{NO}_{2}^{-}, \mathrm{SO}_{4}^{2-}, \mathrm{Cl}^{-}, \mathrm{HS}^{-}$у воді фільтрату на 100,$0 ; 97,1 ; 99,7 ; 100,0 ; 100,0 ; 99,8 ; 98,1 \%$, відповідно (табл. 2) на 21-шу добу культивування. Ефективність окиснення органічних сполук розведеної води фільтрату відстійника № 3 ЛПТПВ становила 65,6 \% на 21-шу добу культивування (табл. 2).

\section{Таблиця 2}

Вплив культивування $R$. yavorovii IMB В-7620 на хімічний склад фільтрату відстійника № 3 Львівського полігону твердих побутових відходів

\begin{tabular}{|c|c|c|c|c|c|}
\hline \multirow{4}{*}{ Показник } & \multicolumn{5}{|c|}{ Концентрація, мг/л } \\
\hline & \multirow{3}{*}{ ГДК** } & \multirow{3}{*}{ Контроль } & \multicolumn{3}{|c|}{ Контроль $+R$. yavorovii IMB B-7620 } \\
\hline & & & \multicolumn{3}{|c|}{ Доба культивування } \\
\hline & & & 7 & 14 & 21 \\
\hline $\mathrm{pH}$ & $6,5-9,0$ & $7,00 \pm 0,01$ & $6,95 \pm 0,01$ & $6,75 \pm 0,01$ & $6,50 \pm 0,02$ \\
\hline Fe загальний & 0,5 & $2,40 \pm 0,01^{*}$ & $1,40 \pm 0,01^{*}$ & $1,20 \pm 0,02 *$ & $0,00 \pm 0,04 *$ \\
\hline $\mathrm{Ca}^{2+}$ & 46,0 & $480,0 \pm 0,04 *$ & $320,0 \pm 0,01^{*}$ & $102,40 \pm 0,06^{*}$ & $13,80 \pm 0,03$ \\
\hline $\mathrm{Mg}^{2+}$ & 50,0 & $315,20 \pm 0,04 *$ & $125,70 \pm 0,05^{*}$ & $75,30 \pm 0,04$ & $1,0 \pm 0,02 *$ \\
\hline $\mathrm{NO}_{3}^{-}$ & 12,5 & $1,20 \pm 0,04 *$ & $0,50 \pm 0,05^{*}$ & $0,00 \pm 0,02 *$ & $0,00 \pm 0,03 *$ \\
\hline $\mathrm{NO}_{2}^{-}$ & 1,5 & $0,34 \pm 0,05^{*}$ & $0,00 \pm 0,01 *$ & $0,00 \pm 0,01 *$ & $0,00 \pm 0,02 *$ \\
\hline $\mathrm{SO}_{4}{ }^{2-}$ & 500,0 & $160,0 \pm 0,02 *$ & $92,0 \pm 0,04 *$ & $23,0 \pm 0,03 *$ & $0,30 \pm 0,03 *$ \\
\hline $\mathrm{Cl}^{-}$ & 300,0 & $549,40 \pm 0,01$ & $311,20 \pm 0,03$ & $101,40 \pm 0,04 *$ & $10,20 \pm 0,04^{*}$ \\
\hline $\mathrm{HS}^{-}$ & 1,0 & $81,0 \pm 0,02 *$ & $25,30 \pm 0,02 *$ & $7,90 \pm 0,05^{*}$ & $0,80 \pm 0,03$ \\
\hline XCK & 500,0 & $800,00 \pm 0,03$ & $500,0 \pm 0,02$ & $350,0 \pm 0,01$ & $275,0 \pm 0,01$ \\
\hline
\end{tabular}

Примітки: * ${ }^{*} \leq 0,05 ;$ контроль - розведена в 10 разів вода; ** https://omr.gov.ua/ua/projects/3776.

Нагромадження біомаси мікроорганізмами, а також зменшення вмісту забруднюючих речовин у стічних водах за їхньої участі $є$ дуже важливим та свідчить про перспективу розроблення біотехнологій для очищення забруднених вод. Про використання стічних вод для нагромадження біомаси фотосинтезувальних бактерій повідомляли раніше: досліджували використання відходів цукрового заводу (Vincenzini et al., 1982; Bolliger et al., 1985), переробки апельсинів (Mitsui et al., 1985), сировинного крохмалю (Buranakarl et al., 1985), відходів лікеро-горілчаної промисловості (Rajani et al., 2016) за участю бактерій. Встановлена нами можливість впливу бактерій $R$. yavorovii IMB B-7620 на зменшення вмісту загального $\mathrm{Fe}, \mathrm{Ca}^{2+}, \mathrm{Mg}^{2+}$, $\mathrm{NO}_{3}^{-}, \mathrm{NO}_{2}^{-}, \mathrm{SO}_{4}^{2-}, \mathrm{Cl}^{-}, \mathrm{HS}^{-}$у стічних водах доповнює та розширює розуміння ролі пурпурових несіркових бактерій в екосистемах, що можуть суттєво впливати на біогеохімічні цикли цих сполук у природі. Отримані результати можуть стати основою для розробки ефективних біотехнологій очищення стічних вод від сірководню, хлору, сполук феруму, нітрогену, сульфуру за участю цих мікроорганізмів.

\section{Висновки}

Отже, встановлено, що бактерії $R$. yavorovii IMB B-7620 найкраще ростуть у стічній воді дріжджового заводу та воді фільтрату відстійника № 3 Львівського полігону твердих побутових відходів за їхнього розведення у 10 разів. Під час росту у стічній воді дріжджового заводу бактерії нагромаджують вдвічі вищу біомасу, ніж у воді фільтрату відстійника № 3 ЛПТПВ. На 21-шу добу культивування бактерій у воді дріжджового заводу рН збільшилося від 7,0 (контроль) до 8,0. Культивування бактерій у цій воді

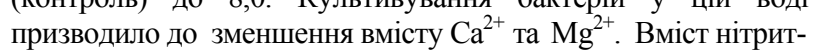

та нітрат-йонів знижувався на 52,7 і 52,7 \% відповідно, сульфат-йонів - на $67,0 \%, \mathrm{Cl}^{-}$- на 40,1\%. Концентрація гідросульфід-йонів знизилась на 94,7 \%. На 21-шу добу росту бактерій у воді фільтрату відстійника № 3 ЛПТПВ іiі $\mathrm{pH}$ знизився від 7,0 (контроль) до 6,5 та зменшився вміст загального $\mathrm{Fe}, \mathrm{Ca}^{2+}, \mathrm{Mg}^{2+}, \mathrm{NO}_{3}^{-}, \mathrm{NO}_{2}^{-}, \mathrm{SO}_{4}{ }^{2-}, \mathrm{Cl}^{-}, \mathrm{HS}^{-}$на 100,0 ; 97,1; 99,7; 100,0; 100,0; 99,8; 98,1 \% відповідно. Ефективність окиснення органічних сполук стічної води дріжджового заводу та води фільтрату відстійника № 3 ЛПТПВ, визначена за хімічним споживанням кисню, становила 42,3 та $65,6 \%$, відповідно на 21-шу добу культивування. Таким чином, доведено, що під час росту у стічній воді дріжджового заводу та воді фільтрату відстійника № 3 ЛПТПВ $R$. yavorovii IMB B-7620 нагромаджують біомасу 2,2; 1,1 г/л відповідно. За їхньої участі у стічних водах відбувається суттєве зменшення вмісту забруднюючих речовин.

\section{References}

Berry, D. F., Francis, A. J., Bollag, J. M. (1987). Microbial metabolism of homocyclic and heterocyclic aromatic compounds under anaerobic conditions. Microbiol. Rev., 51, 43-59.

Bolliger, R., Zurrer, H., Bachofen, R. (1985). Photoproduction of molecular hydrogen from waste water of a sugar refinery by photosynthetic bacteria, Appl. Microbiol. Biotechnol., 23, 147-151.

Buranakarl, L., Cheng-ying, F. K., Izake, K., Takahashi, H. (1985). Production of molecular hydrogen by photosynthetic Agricul. Biol. Chem., 40(11), 3339-3342.

Choorit, W., Thanahoset, P., Thongpradistha, J., Sasaki K., Noparatnaraporn N. (2002). Identification and cultivation of photosynthetic bacteria in wastewater from a 
concentrated latex processing factory. Biotechnol. Letter., 24(13), 1055-1058.

Dmitrijeva, O. O., Kalashnikova, V. O., Koldoba, I. V. (2003). Vodovidvedennja $v$ naselenyh punktah Ukrai'ny ta naprjamky jogo uporjadkuvannja [Drainage in settlements of Ukraine and directions of its ordering]. Ekol. dovk. ta bezpeka zhyttjedijal'nosti, 3, 63-68 (in Ukrainian).

Fomin, G. S. (2008). Voda. Kontrol' toksicheskoj, bakterial'noj i radiacionnoj bezopasnosti po mezhdunarodnym standartam: jenciklopedicheskij spravochnik. 3-e izd., pererab. i dop. [Water. Monitoring toxic, bacterial and radiation safety according to international standards: an encyclopedic guide. 3rd ed., revised. and add]. Protektor, Moscow (in Russian).

Gibbon, D. T, Saylor, G. S. (1992). Scientific foundations for bioremediation, American society for microbiology, Washington.

Granger, D. L., Taintor, R. R., Boockvar, K. S., Hibbs, J. B. (1996). Measurement of nitrate and nitrite in biological samples using nitrate reductase and Griess reaction. Methods Enzymol., 268,142-51.

Gudz, S. P., Horishnyj, M. B., Hnatush, S. O. (2011). Bakterial'nyj fotosyntez: navch. posib.: dlja stud. vyshh. navch. zakl. [Bacterial photosynthesis: a textbook for students of higher education institutions]. Lviv. Nac. Univ. imeni Ivana Franka. Ser. Biol. Stud., Lviv (in Ukrainian).

Gudz, S. P., Hnatush, S. O., Yavorska, G. V., Bilinska, I. S., Borsukevych, B. M. (2014). Praktykum z mikrobiologii': pidruchnyk [Workshop on microbiology: textbook]. Lviv. Nac. Univ. imeni Ivana Franka. Ser. Biol. Stud., Lviv (in Ukrainian).

Hiraishi, A., Shi J. L., Kitamura, H. (1989). Effects of organic nutrient strength on the purple non-sulfur bacterial content and metabolic activity of photosynthetic sludge for wastewater treatment. J. Fermentation Bioengineering, 68, 269-276.

https://omr.gov.ua/ua/projects/3776

Lakyn, G. F. (1990). Biometryja [Biometrics]. Vyshha shkola, Moscow (in Russian).

Lur'e, Ju. Ju. (1984). Analiticheskaja himija prirodnyh i stochnyh vod [Analytical chemistry of natural and waste waters]. Himija, Moscow (in Russian).

Merugu, R., Garimella, S., Kudle, K. R., Malothu, R., Eppakayala, L. (2017). An update on bioremediation potentials of purple non sulphur phototrophic bacteria. J. of Chemical and Pharmaceutical Sci., 10(4), 1530-1537.

Mircha, P. C., Behera, N., Senapati, B. K., Guru, B. C. (1995). Advances in Ecology and Environmental Sciences. Published by: Nangia S.B. for Ashish publishing house, New Delhi.

Mitsui, A., Matsunaga, T., Ikemoto, H., Renuka, B. R. (1985). Organic and inorganic waste treatment and simultaneous photoproduction of hydrogen by immobilized photosynthetic bacteria. Developent in Ind. Microbiol., 26, 209-222.

Nagadomi, H., Takahasi, T., Sasaki, K., Yang, H. C. (2000). Simultaneous removal of chemical oxygen demand and nitrate in aerobic treatment of sewage wastewater using an immobilized photosynthetic bacterium of porous ceramic plates, World J. of Microbiol. and Biotechnol., 16 (1), 57-62.

Nakadomi, H., Hiromatsu, T., Takeno, K., Watanabe, M., Sasaki, K. (1999). Treatment of aquarium water by denitrifying photosynthetic bacteria using immobilized polyvinyl alcohol beads. J. of Biosci. Bioengineering., 87, 625-629.

Oswald, W. J., Gotaas H. B. (1975). Photosynthesis in sewage treatment. Proc. Am. Soc. Civil Engineering., 81, 1-27.
Rajani, B., Sunil Kumar, R., Uma Devi, M., Nayak, J. B. (2016). Role of purple non-sulfur bacteria Rhodopseudomonas palustris RSOU000 and Rhodopseudomonas thermotolerance RSOU555 in waste water treatment. World J. of Pharmacy and Pharmaceutical Sci., 5(8), 1379-1387.

Rhykerd, R. L, Crews, B., McInnes, K. J., Weaver, R. W. (1999). Impact of bulking agents, forced aeration, and tillage on remediation of oil-contaminated soil. Bioresearch Tech., 67, 279-285.

Sasikala, Ch., Ramana, Ch. V., Rao, P. R., Kovacs, K. L. (1993). Anoxygenic phototrophic bacteria: physiology and advances in hydrogen production technology. Adv. in Appl. Microbiol., 38, 211-295.

Sugiyama, M. (2002). Reagent composition for measuring hydrogen sulfide and method for measuring hydrogen sulfide. United States Patent. № 6340596.

Tarabas, O. V., Gnatush, S. O., Ostash, B. O., Mutenko, G. V., Koshla, O. V. (2017a). Identyfikacija purpurovyh nesirkovyh bakterij Rhodopseudomonas sp. Ya-2016 [Identification of purple non-sulfur bacteria of Rhodopseudomonas sp. Ya2016]. Visn. Lviv. un-tu. Ser. biol., 75, 140-145 (in Ukrainian).

Tarabas, O. V., Hnatush, S. O., Moroz, O. M., Vasilechko, V. O., Grishhuk, G. V., Zvir, G. I., Komplikevich, S. J. (2017b). Vykorystannja sul'fid- ta tiosul'fat-joniv purpurovymy nesirkovymy bakterijamy Rhodopseudomonas yavorovii Ya2016 [The usage of sulfide and thiosulfate ions by purple nonsulfur bacteria Rhodopseudomonas yavorovii Ya-2016]. Biosystems Diversity, 25(3), 181-185 (in Ukrainian).

Tarabas, O. V., Hnatush, S. O., Halushka A. A., Moroz O. M. (2018). Pigmenty Rhodopseudomonas yavorovii IMV V-7620 [Pigment compounds of Rhodopseudomonas yavorovii IMV V-7620]. Mikrobiol. biotehnol., 1, 57-65 (in Ukrainian).

Thomas, G. M., Ward, C. H., Raymond, R. L., Wilson, J. T., Loehr, R. C. (1992). Bioremediation, in: encyclopedia of microbiology. Academic Press, London, 369-385.

Togachynska, O. V., Nychyk, O. V., Salavor, O.M., 2014. Normuvannja antropogennogo navantazhennja na naukolyshnje seredovyshhe [Elektronnyj resurs]: konspekt lekcij dlja stud. spec. 6.04.01.06 «Ekologija, ohorona navkolyshn'ogo seredovyshha ta zbalansovane pryrodokorystuvannja» den. ta zaoch. form navchannja [Rattioning of anthropogenic load on the environment. [Electronic resourse]: lectures note for students spec. 6.04.01.06 «Ecology, environmental protection and balanced environmental management» full-time and correspondence forms of study]. Nac. Univ. Harch. Tehnol, Kyjiv (in Ukrainian).

Vasavi, D., Ramchander, M., Girisham, S., Reddy, S. M. (2008). Remediation of waste water using two anoxygenic phototrophic bacteria. Ecol. Environ. \& Consers, 14, 363-366.

Vincenzini, M., Materassi, R., Tredici, M. R., Florenzano, G. (1982). Hydrogen production by immobilized cells, I. Light Dependent dissimilation of organic substances by Rhodopseudomonas palustris. Intern. J. of Hydrogen Energy, 7(9), 231-236.

Weaver, P. F., Wall, J. D., Gest, H. (1975). Characterisation of Rhodopseudomonas capsulata. Arch. Microbiol., 105, 207-216.

Zapolskij, A. K., Saljuk, A. I. (2008). Osnovi ekologiï [Principles of ecology]. Vyshha shkola, Kyjiv (in Ukrainian).

Zerkalov, V. (2007). Ekologichna bezpeka: upravlinnja, monitoring, kontrol. Posibnik [Environmental safety: management, monitoring, control. Manual]. Dakor. Osnova, Kyjiv (in Ukrainian). 